\title{
Laziness: A Literary-Historical Perspective
}

\author{
Michael Greaney
}

Abstract This chapter originated from talks Michael Greaney delivered at two Hubbub events: 'Sloth: What's in a Name?' and the 'Science and Politics of Laziness', which took place at London Zoo and Wellcome Collection, respectively. Here, Michael draws on literary history, cultural associations and the poetic resonances of the concept of sloth, and considers laziness and inactivity from a literary perspective.

Keywords Attention economy · Laziness · Leisure · Sloth · Work ethic

Laziness - whether in the sense of an allergy to effort, a morally questionable reluctance to pull your weight when there is work to be done, a fondness for shortcuts, or a well-developed appetite for the pleasures of idleness - has probably always been with us. In fact, laziness may well be part and parcel of what it means to be human. A machine could never be lazy; nor, it might be argued, could an animal. Some members of the animal kingdom are lazy by reputation (cats, koalas, possums) or by name (sloths), but when we accuse such creatures of work-shy behaviour, we

\footnotetext{
M. Greaney $(\square)$

Lancaster University, Lancaster, United Kingdom

e-mail: m.greaney@lancaster.ac.uk

(C) The Author(s) 2016

F. Callard et al. (eds.), The Restless Compendium, DOI 10.1007/978-3-319-45264-7_22
} 
are exhibiting our all-too-human habit of seeing aspects of ourselves in non-human creatures. What, then, should we make of our human monopoly on laziness? Should we be proud of our status as the lazy animal? And what can literary and cultural texts - so often dominated by stories of heroic effort, desperate struggle, titanic conflict and epic journeying tell us about the unambitiously sedentary and work-shy side of human experience?

If you are looking for a symbolic moment when laziness became a possibility within the range of human behaviours, you could do a lot worse than point to the scene in the Bible where Adam and Eve are expelled from the Garden of Eden with the words of God ringing in their ears: 'In the sweat of thy face shalt thou eat bread' (Genesis 3.19). Hard work is a crucial element of the punishment meted out by God for humankind's disobedience. Cast out from the presence of God, Adam and Eve and their descendants are obliged to toil in order to feed themselves; but in the longer term, gruelling labour will be part of humankind's redemption in the eyes of God. Laziness - the disinclination to work - is thus implicitly established as something that we simply can't afford if we are at all interested in physical or spiritual survival; it is a vice that will in due course take its place alongside avarice, envy, gluttony, lust, pride and wrath in the catalogue of depravity that is the Seven Deadly Sins, versions of which have been circulating in one form or another since Pope Gregory I first drew up the list in the sixth century AD.

Definitions of the sin of laziness have changed notably over the centuries. What we now call sloth was originally understood as an occupational hazard for the early Christians known as the Desert Fathers, the hermits and monks whose punishing regimes of piety, prayer and selfdenial exposed them to the temptations of demotivation and listlessness and a sorrowfully distracted state of torpor known as acedia. ${ }^{i}$ In the medieval period, as sloth superseded acedia in the religious vocabulary of the time, the concept broadened to encompass all forms of sinful inactivity and work-shy idleness, from the neglect of everyday chores to falling asleep in church. Physical sloth became a favourite topic for the compact fables known as exempla that circulated widely in this period, not least because of the vivid kinds of poetic justice that could be meted out to those who indulged in sinful levels of inactivity. Tales of people who were victims of their own laziness included the story of the person who was so

${ }^{i}$ Cf. Chap. 3. 
bone idle that when mice started nibbling at his ears he let them munch all the way into his head. Another legendary sluggard had a noose around his neck but couldn't summon up the energy to shake it off. ${ }^{1}$ Too lazy to recognize imminent and lethal threats to their own well-being, slothful people were envisaged in these exempla as a perversely self-punishing bunch whose indolence facilitated its own gruesome comeuppance.

The hair-raisingly severe, even sadistic, punishments meted out for sloth in medieval exempla were not simply preposterous scare stories designed to terrify the gullible into a love of hard work; rather, they would have been understood as conveying a sense of the profound spiritual dangers of laziness. Sloth was a gateway sin, a seductively effortless shortcut to self-destruction. If you lack the self-discipline to resist laziness, then the other six deadly sins - and with them the prospect of eternal damnation aren't far away.

The most elaborately conceived medieval 'map' of sinfulness and its consequences can be found in Dante's Divine Comedy (1320), that epic guided tour of the afterlife from the deepest circles of hell to the exalted dwelling place of God, where the poet finds lazy and indolent people on the terrace of sloth on the fourth level of Mount Purgatory. Despite its name, the terrace of sloth is a hive of activity, a place where those who were slothful in their lifetimes now charge around with great energy, declaiming cautionary tales about excessive indolence and reciting edifying stories about the virtues of hard work. There is, it has to be said, something faintly comical about this mob of slothful runners frenetically catching up on all the exertion they thought they had dodged in their lifetimes. In Dante's imagination, any labour we shirk in our time on earth is simply being deferred until the afterlife.

From the Bible to early Christian theology to medieval literature, it is possible to trace the emergence of what we would now call the 'work ethic', the notion that labour and exertion are indispensable sources of value, dignity and meaning in human experience. ${ }^{\text {ii }}$ Nor does the work ethic vanish with the onset of the Enlightenment and industrial modernity in the eighteenth and nineteenth centuries. One of the great hymns to the work ethic in English literature is Daniel Defoe's classic desert island narrative Robinson Crusoe (1719), in which Defoe's castaway misses no opportunity to remind us just how heroically unslothful he has been, just how relentlessly he has toiled to convert a hostile environment into a place

\footnotetext{
ii See Chap. 21.
} 
where he cannot just survive but thrive and prosper. One of Crusoe's favourite expressions is infinite labour. ${ }^{2}$ With 'infinite labour', he tells us, he salvages material from his wrecked ship, masters the use of tools for the first time, chops down trees for building materials and firewood, constructs a fortified shelter, and provides himself with the means to cook and prepare food. But what is infinite labour? Can human effort ever truly be infinite in the sense of limitless, unrestricted and never ending? ?iii Crusoe's self-congratulatory language sounds a lot like the eighteenth-century equivalent of the person who stresses their dedication to a given project by declaring that she/he is going to give 100 per cent to it or the authority figure who solemnly pledges that we will not rest until a problem has been solved, as though rest is an optional extra than can be subtracted from a given human endeavour at no cost either to the success of the endeavour or indeed to the humanity of those who undertake it.

For all its prevalence in the modern imagination, the work ethic that is celebrated by Defoe and embodied by Crusoe is not without its notable dissenters. Conspicuous among these last is the most radically lazy person in nineteenth-century fiction, Bartleby the Scrivener, the enigmatically and obdurately passive legal clerk in Herman Melville's eponymous novella of 1853. Notoriously, Bartleby would 'prefer not to' do anything that his employers ask of him, and he makes this preference a point of principle from which he absolutely will not budge. Melville's mild-mannered refusenik goes on a kind of indefinite one-man strike, but it's not a campaign for better pay or conditions; rather, it's almost an existential strike, a systematic campaign of resistance to the way in which our lives can be defined by the dreary monotony of work. It has to be said that Bartleby makes not working look anything but easy. To be as completely passive as Bartleby in the face of all the pressure that conventional society can muster - would take huge reserves of stubbornness and self-control. Given that the easiest thing for Bartleby would be to put in a more or less half-hearted day at the office, maybe the really slothful people in the story are the other characters who gladly take the path of least resistance and carry on working.

In addition to giving us Melville's fictional virtuoso of idleness, the nineteenth century would also witness the emergence of the laziness manifesto, a genre famously exemplified by 'The Right to Be Lazy' (1880), a vehement denunciation by the French anarchist Paul Lafargue of 'the priests, the economists and the moralists [who] have cast a sacred halo

iii Cf. Chap. 23. 
over work'. ${ }^{3}$ Almost exactly 100 years after Lafargue's manifesto, there appeared an interview with the French cultural theorist Roland Barthes under the title 'Dare to Be Lazy' (1979), in which Barthes reprimands himself for being insufficiently committed to his own indolence. ${ }^{4}$ It is worth asking whether, in the early twenty-first century, it is as daring or naughty as it once was to give ourselves permission to be lazy. Surely, by this stage of human history, mechanized technology should be taking care of most of the relentless and backbreaking toil that has been the lot of humankind ever since Adam and Eve were given their marching orders from Eden? Surely those of us who are lucky enough to live in reasonably affluent societies, with access to all manner of labour-saving devices, are in a position to enjoy the kind of leisure that our ancestors only dreamed of?

Reflecting on the emergence of the leisure society in the twentieth century, the sociologist Robert Stebbins has argued that it gave rise to a new category of person: homo otiosus, or 'person of leisure', a person defined by recreational pursuits rather than by what they do at work. ${ }^{5}$, iv In the era of homo otiosus, it may seem that we've long since abandoned the notion that laziness is a self-evidently punishable behaviour. However, censorious attitudes to real or perceived laziness have not gone away. "Where is the fairness', asked the UK chancellor George Osborne at the 2012 Conservative party conference, 'for the shift-worker leaving home in the dark hours of the early morning who looks up at the closed blinds of their next-door neighbour sleeping off a life on benefits?' Osborne's modern-day exemplum invites us to look at but not through those closed blinds because he is satisfied with his preconceptions about what's behind them - a grubby benefit addict whose reliance on state support is a lifestyle choice rather than the product of poverty, illness or structural inequality. The blindness and, indeed, the laziness - in Osborne's rhetoric lies in its inability to imagine recipients of state support as anything other than lazy, hedonistic parasites."

Osborne's polarizing rhetoric suggests that even in the era of homo otiosus, with its techno-utopian dream of leisure for all, the old division between virtuous workers and delinquent shirkers has lost none of its polemical force. The impulse to punish sloth is as strong as it ever was. Let's consider, in this regard, one of the most powerful, if disturbing, visions of punished sloth in modern cinema. The film is David Fincher's Seven (1995), a neo-noir thriller in which a pair of homicide detectives

\footnotetext{
iv Cf. Chap. 8.

${ }^{v}$ See Chap. 21.
} 
played by Morgan Freeman and Brad Pitt track a serial killer who expresses his murderous contempt for the modern world by taking the lives of seven people in seven days, each killing orchestrated in such a way as to deliver a gruesome symbolic punishment for one of the Seven Deadly Sins. No one who has seen this movie is likely to forget the scene in which the representative of 'Sloth' is discovered, strapped to his bed, emaciated and clinging to life - a scene that gives us a ringside seat on the ritualized slaughter of homo otiosus. But, at the same time, no one who watches the movie is expected to share the killer's morality, such as it is. The truly malevolent person in Seven is not the representative of sloth but his antithesis, the atrociously thorough, meticulous and obsessive killer who works so relentlessly at his craft. Which is to say that Fincher's movie, rather than preaching the virtues of hard work, actually demonizes those who demonize laziness. Even so, there are subtle ways in which his narrative serves to reinforce the work ethic. After all, Seven is one of those films which revolves around the cliché of the veteran detective who catches the biggest case of his career the very week he is set to retire. Of all the fears explored by this macabre movie, the fear of doing nothing is arguably the most subtly pervasive, and a new case, even one as disturbing as Morgan Freeman's last, grants the detective an 11th-hour reprieve from something as unimaginable, in its own way, as the serial killer's crimes - the prospect of unstructured time that looms so emptily in front of the soon-to-be-retired detective.

The work ethic is curiously resilient. Even though it may seem high time that we abandoned its dour imperatives in a bid to inaugurate an era of guilt-free laziness, the celebration of idleness can seem like hard work, not least because, in the contemporary world, it's increasingly difficult to tell the one from the other. Every time one of us checks a smartphone, it could be to receive an invitation to a party, confirm a holiday booking or read a work email that can't be ignored - but whether it's a matter of business or pleasure, we are always checking in, reporting for duty as loyal operatives in what is becoming known as the attention economy. And it seems to me that the relentlessness with which we pay attention - and I think we can take the word pay literally in this context - suggests that there are no limits to the attention economy. We carry it around with us and take it home with us; wherever we go, it's already there. If one of the effects of contemporary technology is to make us work even when we think we are playing, then the attention economy has succeeded in finding ways of capturing infinite labour from homo otiosus. Once upon a time, the work ethic 
taught us that human beings cannot afford to be lazy; however, if we are going to avoid being defined as creatures of the attention economy, then we can't afford not to be lazy. In fact, we're probably going to have to roll up our sleeves and work at it.

\section{Notes}

1. See Siegfried Wenzel, The Sin of Sloth: Acedia in Medieval Thought and Literature (Chapel Hill, N.C.: University of North Carolina Press, 1967), 112.

2. Daniel Defoe, The Life and Strange Surprizing Adventures of Robinson Crusoe of York, Mariner: Who Lived Eight and Twenty Years, All Alone in an Un-Inhabited Island on the Coast of America, near the Mouth of the Great River of Oroonoque, Having Been Cast on Shore by Shipwreck, Wherein All the Men Perished but Himself with an Account How He Was at Last as Strangely Deliver'd by Pyrates, Written by Himself, ed. J. Donald Crowley (Oxford and New York, N.Y.: Oxford University Press, 1998), 56, 59, 68, 122, 127, 152.

3. Paul Lafargue, The Right to Be Lazy (Chicago, III.: Charles H. Kerr, 1883), 9.

4. Roland Barthes, 'Dare to Be Lazy', in The Grain of the Voice, Interviews 1962-1980, trans. Linda Coverdale (Berkeley, Calif.: University of California Press, 1985).

5. Robert A. Stebbins, Personal Decisions in the Public Square: Beyond Problem Solving into a Positive Sociology (New Brunswick, N.J.: Transaction Publishers, 2009), 5 .

\section{FURTHER READING}

Diski, Jenny. On Trying to Keep Still. London: Virago, 2007.

Pynchon, Thomas 'The Deadly Sins/Sloth: Nearer My Couch to Thee'. The New York Times Book Review, 6 June 1993.

Rushdie, Salman. 'Notes on Sloth from Saligia to Oblomov'. Granta 109 (2009): 67-80.

Taylor, Gabriele. Deadly Vices. Oxford: Oxford University Press. 2006.

Michael Greaney is an academic at Lancaster University (Department of English and Creative Writing). He researches modern/contemporary fiction and theory, and is currently writing a book on the representation of sleep and sleep-related states in the modern novel. 


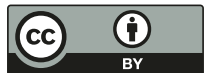

This chapter is distributed under the terms of the Creative Commons Attribution 4.0 International License (http://creativecommons.org/ licenses/by/4.0/), which permits use, duplication, adaptation, distribution and reproduction in any medium or format, as long as you give appropriate credit to the original author(s) and the source, a link is provided to the Creative Commons license and any changes made are indicated.

The images or other third party material in this chapter are included in the work's Creative Commons license, unless indicated otherwise in the credit line; if such material is not included in the work's Creative Commons license and the respective action is not permitted by statutory regulation, users will need to obtain permission from the license holder to duplicate, adapt or reproduce the material. 